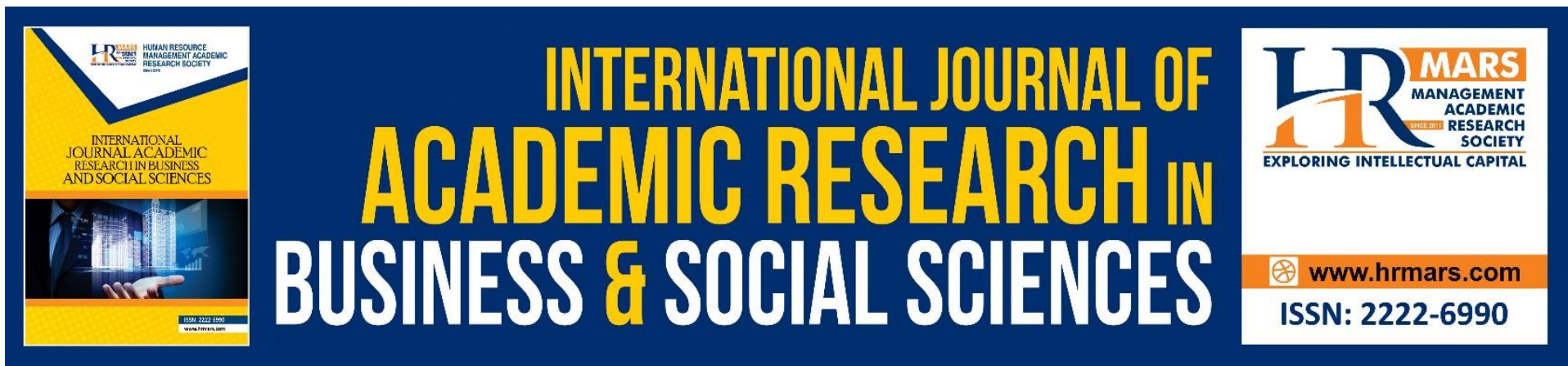

\title{
Sentence Construction Errors among Malay Arabic Learners at Universiti Sultan Zainal Abidin
}

Aliyu Abdullahi, Nurazan Binti Mohmad Rouyan, Siti Salwa binti Mohd Noor, Zulazhan bin Ab. Halim

To Link this Article: http://dx.doi.org/10.6007/IJARBSS/v8-i6/4293

DOI: $\quad 10.6007 /$ IJARBSS/v8-i6/4293

Received: 24 May 2018, Revised: 26 June 2018, Accepted: 30 June 2018

Published Online: 08 July 2018

In-Text Citation: (Abdullahi, Rouyan, Noor, \& Halim, 2018)

To Cite this Article: Abdullahi, A., Rouyan, N. B. M., Noor, S. S. binti M., \& Halim, Z. bin A. (2018). Sentence Construction Errors among Malay Arabic Learners at Universiti Sultan Zainal Abidin. International Journal of Academic Research in Business and Social Sciences, 8(6), 953-966.

Copyright: (c) 2018 The Author(s)

Published by Human Resource Management Academic Research Society (www.hrmars.com)

This article is published under the Creative Commons Attribution (CC BY 4.0) license. Anyone may reproduce, distribute, translate and create derivative works of this article (for both commercial and non-commercial purposes), subject to full attribution to the original publication and authors. The full terms of this license may be seen

at: http://creativecommons.org/licences/by/4.0/legalcode

Vol. 8, No. 6, June 2018, Pg. 953 - 966

http://hrmars.com/index.php/pages/detail/IJARBSS

JOURNAL HOMEPAGE

Full Terms \& Conditions of access and use can be found at http://hrmars.com/index.php/pages/detail/publication-ethics 


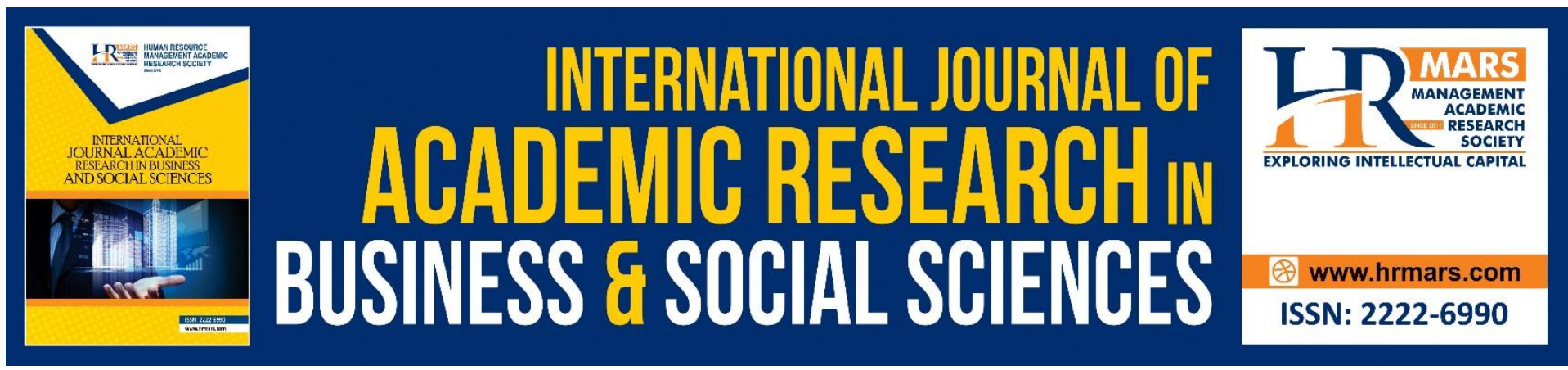

\title{
Sentence Construction Errors among Malay Arabic Learners at Universiti Sultan Zainal Abidin
}

\author{
${ }^{1}$ Aliyu Abdullahi, ${ }^{2}$ Nurazan Binti Mohmad Rouyan, ${ }^{3}$ Siti Salwa \\ binti Mohd Noor, ${ }^{4}$ Zulazhan bin Ab. Halim \\ 1, 2, Centre of Arabic Language Studies, Faculty of Languages and Communication Universiti \\ Sultan Zainal Abidin (UniSZA), 21300 Kuala Nerus, Terengganu, Malaysia. \\ Email:aambyl13@gmail.com
}

\begin{abstract}
It is generally accepted that the efficiency of written Arabic counts on the grammatical accuracy. This research investigates the sentence fragment as one of the foremost errors encountered by Malay undergraduate students in their Arabic written composition. It intended to discover fragment, its frequency and the causes of the fragments. The research employed a mixed method approach. The subjects of the research comprised 30 students selected from the final year students of the Universiti Sultan Zainal Abidin Terengannu, Malaysia. Achievement Test and Questionnaire were the instruments used to collect the data. Markin software version 4.2.4.1 and Statistical Package for Social Science (SPSS) version 23.0 is used to analyse the data. The result of the study revealed that the students produced a total number of 91 fragments with the frequency in decreasing order as follows, misuse of articles $31(34.0 \%)$ instances, omission of verb 19(21.0\%) instances, omission of subject $17(19.0 \%)$, spelling errors $15(16.0 \%)$ instances, omission of object $6(7.0 \%)$ omission of both subject and verb 3(3.0\%). The main causes of fragments were attributed to intralingual sources and other factors explored are related to teachers and students attitudes towards correction and other issues related to written Arabic.
\end{abstract}

Keywords: Arabic, Errors, Malay Students, SLA, Sentence Fragment, Writing skills.

\section{Introduction}

Error Analysis entails the analysis of so many linguistic items in language use and learning. In written language Ferris, (2011) lists and estimates about forty of errors committed by second language learners. A sentence fragment is the second in the list of the ten most commonly found errors. Arabic is one of the most predominantly spoken and written languages in the world and used for the widest multiplicity of purposes (Coulmas, 2017). 
Arabic language is one of the educational media of communication and spoken as Second Language in Malaysia (Haron et al., 2016; Ting, 2017). Studies by Jaafar (2011) and Ahmad (2003) state that students' weak competence in writing Arabic fallout from lack of learning the method to construct sentences. Mei and Mohd (2017) stated that disorderly use of general academic writing skills is the cause of low scores among Malay students in their Arabic examinations. The main objective of this study is to investigate the level of students' composing ability in written Arabic. However, it intends to achieve the following objectives: To observe the erroneous sentence fragments produced by final year Arabic students in their writing at UniSZA; to identify what causes sentence fragments in the Arabic students' writing; to discover other factors contributing to sentence errors in the students writing. Thus, this study is limited to sentence boundaries and entailed a detailed analysis of sentence fragments found in undergraduate students writing. Essay writing is used as the instrument to collect the data from the corpora of 30 students 11 male and 19 female and questionnaires are administered to the same students as well, to collect some basic information of the students and to find out other factors contributing to sentential errors in students writing. This study contributed to second language research and provided researchers with evidence on how the Arabic language is learned in reference to composition competence.

\section{Problem Statement}

The problem of poor writing performance of the students in the examination catches the attention of many second language investigators, Some of them focus on finding out how writing influences the performance of students, what factors are responsible for errors in students' compositions and how to get free of them (Harpin, 2017). However, the effectiveness of any writing is determined by grammatical correctness (Shintani and Ellis, 2015). The Malaysian Ministry of Education has recognised that essay-writing is the main problem for students to obtain essential marks in the examination (Veloo, Krishnasamy, \& Harun, 2015). Jaafar (2011) and Ahmad (2003) argue that students' poor performance in writing Arabic results from poor learning method particularly sentences construct. Additionally, studies indicate that writing skill is not a simple task and cannot be simply achieved without any proper practices due to being a difficult cognitive activity that requires five main levels: thematic, paragraph, sentence, grammar, and lexical (Lavelle, Smith, \& O’Ryan, 2002).

Because of such problems, students face many writing skills problems and are often disappointed (Scott \& Vitale, 2003). They recognise that these challenges shadow from basic mechanical problems such as spelling, idea, and punctuation to higher cognitive and metacognitive problems. Due to this disturbing issue, it is important that the affecting factors be considered and learned by language teachers and curriculum makers. Different factors influence students' performance in writing as confirmed by many studies.

The recent researches confirmed that the problems of learning Arabic among Malay students are still existing despites struggles made by government policies and different 
models and approaches adopted by many researchers (Alhirtani, 2018; Mohad, Mokhtar, \& Omar, 2018; Zailaini et al., 2018; Al-Sobhi et al., 2017; Rahman, 2017).

\section{Literature Review}

With a particular recommendation to any research study of factors impacting SLA, Pienemann, and Kessler, (2012) recommend, "When an effort is made to figure out factors affecting the development of language proficiency, one is instantly confronted with the issue of determining effectiveness itself" ( $p$ 67). This opinion searches again a short discussion on the problem of language testing in this literature review, not only because it has been a huge part of this research, yet much more importantly, language testing could highlight the result or achievement, therefore, showing success or failing in 2 nd language learning.

One of the crucial problems in any assessment of language efficiency is reflected by just what Brindley (1986) states "The field of Language Efficiency Analysis is overloaded with a variety of confusing terms. Terminologies like "Communicative capability","linguistic competence" "linguisticperformance", "communicative performance", "language effectiveness", "language skill" etc. are widely used in the literature by different authors in different methods" (p. 3). The argument regarding methods of conceptualising the nature of language effectiveness underlies debates which trigger a situation where the concept of language proficiency one holds will inevitably influence the way one deals with evaluating it. There are many kinds of research carried out by second language researchers to investigate the problems faced by second language learners. They employed different approaches to learner language analysis. Error Analysis is one of the approaches employed to investigate the difficulties L2 learners face in written (Bawa and Watson, 2017).

However, Yahya et al. (2016) use a quantitative approach to investigate writing of Malaysian undergraduate Arabic learners with the aim of discovering the types of errors they produced in their Arabic writing. The results of the study reveal that errors in the tenses use are most frequent errors made by the participants in which 229 errors were committed by 28 students out of 30 . Other errors comprise of the use of an article, errors in a preposition, errors in using singular and plural, and errors in spelling. It suggested that students should have adequate exposure and practice in the $L 2$. This research lacks vivid display of the types of errors. Furthermore, Hassan (2017) studies errors of written Arabic essays by the Terengganu diploma students of the Arabic language. He collects and analyses essays from 32 corpora written by 27 female and five male students. His study reveals that the student committed ten common errors among which tense miss used has the highest frequency. An investigation into inter-lingual and intra-lingual errors of writers of another language is strongly recommended. The problem of sentence fragment is not given much attention in the previous researches viewed in the literature. This gives the present study a very practical objective to be conducted. 


\section{Method}

The researchers employed a mixed method approach. In line with the set objectives, the study devoted to the descriptive survey. Survey research is chosen to find out "what are sentence fragments?", "what causes sentence fragments?", And "Frequency of the occurrences of sentence fragments in the writing of the UniSZA Arabic learners". The instruments used to collect the data are questionnaire and achievement test. However, the two data sets collected had been analysed separately, while the overall analysis emphasised quantitative approach. The population of the study comprised all final year students in (2017/2018) academic session, studying at the university Sultan Zainul Abidin Terengganu, Malaysia. A total number of 30 students (11 males and 19 females) were selected from the population using purposive sampling technique. The 30 students participated in a test session, and they are the respondents of the questionnaire administered.

\section{Data Analysis}

The study followed the steps of Error Analysis proposed by Corder(1974) for data analysis. Other analytical statistics were employed to analyse the data obtained from the questionnaire (open-ended questions) using SPSS (version 23.0); such as frequency distribution, percentage, mean, mode, and median. The data collected in the achievement test were marked and analysed using Markin software (version 4.2.2.2).

In this study Sentence fragments (pre-coded) were categorised as follows:

1. S.F.E.1 = Omission of Object (OMO)

2. S.F.E.2 = Omission of Subject (OMS)

3. S.F.E.3 = Omission of both Subject and Verb (OSV)

4. S.F.E.4 = Omission of Verb (OV)

5. S.F.E $E_{5}=$ Spelling Error (SERR.)

6. S.F.E $E_{6}=$ Misuse of Articles (MUA.)

\section{Results and Discussions}

This part presents and discusses the data collected from the two phases of the research. It shows the ways data were analysed and entailed the summary of findings obtained from the analysed data based on the guided research questions. It presents the demographic information of sampled respondents extracted from the first four items of the questionnaire administered to them.

\section{Demographic Information of the respondents}

Table 1.0 level, Session of the Study and Nativity of the Respondents

\begin{tabular}{|c|c|c|c|c|}
\hline Statement & Information & $\begin{array}{ll}\text { No. of } \\
\text { respondents }\end{array}$ & Frequency & Percentage (\%) \\
\hline Level & Sem 7 & 30 & 30 & 100.0 \\
\hline Session & $2017 / 2018$ & 30 & 30 & 100.0 \\
\hline Nativity & Malay & 30 & 30 & 100.0 \\
\hline \multirow[t]{2}{*}{ Gender } & Male & 11 & 11 & 36.70 \\
\hline & Female & 19 & 19 & 63.30 \\
\hline Age & $20-25 y r s$ & 30 & 30 & 100.0 \\
\hline
\end{tabular}


The table 1.0 above indicated that all of the respondents were derived from the same range of semester studying in the same session and they are all Malay native language speakers. The respondents' age distribution was measured using item 5 of section A of the questionnaire. It indicated that the age of the respondents was at the range 20-25. This also reflects the possible year for $\boldsymbol{A}$-level students' graduation.

\section{Phase A: Achievement Test QUAL(quan)}

This phase entailed the qualitative approach to the study, in which Achievement Test was used to collect the data. The collection and analysis of the data at this phase are based on 'QUAL(quan)' which meant that quantitative data set is enclosed within the qualitative data set. This indicated that qualitative data were later quantified so that it can be easily interpreted. Coder (1974) steps of Error Analysis were followed at this phase, which comprised the collection, identification, description, interpretation and evaluation of the learners' errors. The data analysed were transferred, quantified and presented in the table below:

Table 2.0 Data Quantification

\begin{tabular}{|c|c|c|c|c|c|c|c|}
\hline \multirow[b]{2}{*}{ participant } & \multicolumn{6}{|c|}{ Annotations } & \multirow[b]{2}{*}{ Instance } \\
\hline & OMO & OMS & OMSV & OMV & SERR & MUA & \\
\hline 1 & 1 & - & - & 2 & 1 & 1 & 5 \\
\hline 2 & - & - & - & - & 1 & - & 1 \\
\hline 3 & - & 1 & - & - & - & 2 & 3 \\
\hline 4 & 2 & 3 & - & 2 & 1 & 2 & 10 \\
\hline 5 & - & - & - & 1 & - & - & 1 \\
\hline 6 & - & - & - & 2 & - & - & 2 \\
\hline 7 & - & - & - & - & 2 & 1 & 3 \\
\hline 8 & - & - & - & 1 & 1 & - & 2 \\
\hline 9 & 1 & 2 & - & - & - & 1 & 4 \\
\hline 10 & - & - & 1 & 1 & - & - & 2 \\
\hline 11 & - & - & - & - & - & - & 0 \\
\hline 12 & - & - & - & 3 & 2 & 3 & 8 \\
\hline 13 & 1 & 1 & - & 1 & - & - & 3 \\
\hline 14 & - & - & - & - & - & - & 0 \\
\hline 15 & - & 2 & 1 & - & 2 & 2 & 7 \\
\hline 16 & - & 1 & - & - & - & - & 1 \\
\hline 17 & - & - & - & - & - & - & 0 \\
\hline 18 & - & 2 & - & - & - & - & 2 \\
\hline 19 & - & 1 & - & - & 1 & 3 & 5 \\
\hline 20 & 1 & - & - & - & 1 & 1 & 3 \\
\hline 21 & - & - & - & 1 & - & 1 & 2 \\
\hline 22 & - & - & - & 1 & - & 4 & 5 \\
\hline 23 & - & - & - & - & 1 & - & 1 \\
\hline 24 & - & 1 & - & - & - & - & 1 \\
\hline 25 & - & 1 & - & - & - & 2 & 3 \\
\hline 26 & - & - & - & 1 & - & - & 1 \\
\hline 27 & - & - & 1 & 2 & 1 & 5 & 9 \\
\hline 28 & - & - & - & - & - & 3 & 3 \\
\hline 29 & - & 2 & - & - & - & - & 2 \\
\hline 30 & - & - & - & 1 & 1 & - & 2 \\
\hline
\end{tabular}


INTERNATIONAL JOURNAL OF ACADEMIC RESEARCH IN BUSINESS AND SOCIAL SCIENCES Vol. 8, No. 6, June 2018, E-ISSN: 2222-6990 @ 2018 HRMARS
Total
6
17
3
19
15
31
91

Results in Table 2.0 indicated the number of the participants, types and some errors appeared in the writing of each participant. The total number of each type of errors is given below the table under each category, and the sum of the overall errors is 91 as calculated. The distribution of the errors is presented in the next table.

Table 3.0 Errors Distribution

\begin{tabular}{llll}
\hline Error Type (Annotation) & Instances & Percentage \\
\hline S.F.E.1 & (Omission of Object) & 6 & $7.0 \%$ \\
S.F.E.2 & (Omission of Subject) & 17 & $19.0 \%$ \\
S.F.E.3 (Omission of Subject \&Verb) & 3 & $3.0 \%$ \\
S.F.E.4 (Omission of Verb) & 19 & $21.0 \%$ \\
S.F.E.5 (Spelling Error) & 15 & $16.0 \%$ \\
S.F.E.6 (Misuse of Article) & 31 & $34.0 \%$ \\
Total & & $\mathbf{9 1}$ & $\mathbf{1 0 0 \%}$ \\
\hline
\end{tabular}

Results in Table 3.0 revealed that S.F.E.6 is the most frequent form of the fragment in the letter written by The Malay undergraduate students at UNISZA, such fragment was found at 31 instances equal to (34.0\%) out of 91 total instances. The result of the study revealed that the students produced a total number of 91 fragments with the frequency in decreasing order as follows, misuse of articles 31(34.0\%) instances, omission of verb $19(21.0 \%)$ instances, omission of subject $17(19.0 \%)$, spelling errors $15(16.0 \%)$ instances, omission of object $6(7.0 \%)$ omission of both subject and verb 3(3.0\%). In general, the results of the study revealed that sentence fragments are commonly appeared frequently in the students' compositions as a total number of 30 students engaged in written test and produced a total number of 91 fragments.

\section{Phase B: Questionnaire QUAN(qual)}

This part of the study sets to supplement the first phase (qualitative). A total of 30 questionnaires were administered to 30 respondents. Section A of the questionnaire presented the demographic information of the respondents have displayed at table 1.0 above, this is because the respondents were the same students who participated in the written test analysed in phase A of the study since the data used in both phases were collected simultaneously. Notwithstanding, Sections B and C of the questionnaire were set to find out other factors that might contribute to the sentence errors among the students by inquiring among other things: students' attitudes and perceptions when dealing with written work concerning error, correction, grammar, and the influence of revision in managing fragments or written errors in general.

Moreover, different variables of section B of the questionnaire have been closely examined employing descriptive statistics to evaluate the responses. The variables were measured using mean value, Standard Deviation and Frequency derived from Likert scales based on 4 points of frequency: $\mathrm{N}=\mathrm{Never}, \mathrm{R}=$ Rare, $\mathrm{S}=$ Sometime, $\mathrm{F}=$ Frequently. Moreover, views of the 
participants are dichotomized into two groups of frequencies, the firsts group is illustrated as $\mathrm{N}+\mathrm{R}$ (never and rarely) and the second group is illustrated as S+F (sometimes and frequently). Admittedly, three levels of effects were considered in the present study as indicated by the mean value: 0. 1-1.99 is considered low, 2.0-2.99 seen as moderate and 3.0-4 is considered high. Thus, the findings are reported within the range of 0.00 to 4.00 . The findings are presented in the following tables based on the variables used in the study:

Table 4.0: Teacher Correction: (Error identification/correction)

\begin{tabular}{|c|c|c|c|c|}
\hline \multirow[t]{2}{*}{ Statement } & \multirow[t]{2}{*}{ Mean } & \multirow[t]{2}{*}{ SD } & \multicolumn{2}{|c|}{ Total (\%) } \\
\hline & & & $\mathrm{N}+\mathrm{R}$ & $\mathrm{S}+\mathrm{F}$ \\
\hline $\begin{array}{l}\text { 6. My Arabic teacher underlines/circles all of my } \\
\text { grammatical errors. }\end{array}$ & 3.10 & 1.06 & 30 & 70 \\
\hline $\begin{array}{l}\text { 7. My Arabic teacher gives feedback by making } \\
\text { comments without correction. }\end{array}$ & 2.86 & 0.97 & 30 & 70 \\
\hline $\begin{array}{l}\text { 8. My Arabic teacher gives feedback by giving codes } \\
\text { of errors such as: 'SP' for spelling, ' } V \text { ' for a verb, } \\
\text { 'FRAG' for a fragment, 'ADJ' for an adjective, 'GR' } \\
\text { for grammar ' } P \text { ' punctuation etc. }\end{array}$ & 2.40 & 1.13 & 56.7 & 43.3 \\
\hline Total & 2.78 & 1.05 & 38.9 & 61.1 \\
\hline
\end{tabular}
Level of indicator: Low =0.-1.99; moderate=2.0-2.99; high=3.0-4.0

The result in table 4.0 above revealed a moderate mean (2.78) rating of overall beliefs of students concerning teacher correction. Items 6-8 required students to give a reflection of their teachers when dealing with their errors and kind of the feedback the teachers' preferred. Item 6 shows a positive high mean 3.10 (70\%) and item 7 revealed a different mean of 2.86 with $70 \%$ majority while item 8 of revealed a mean 2.40 with the $56.7 \%$ majority but in reverse case of the two items above here the majority is from the side of negativity.

In summary, the results obtained from the above table indicated that majority of the students believed that their teachers preferred to give a correction by both underlining or cycling and the same time it indicated that those teachers preferred to give feedback without correction. As item 8 indicated that majority believed that their teachers are not using codes when giving feedbacks. 
Table 5.0: Forms of Correction

\begin{tabular}{|c|c|c|c|c|}
\hline \multirow[t]{2}{*}{ Statement } & \multirow[t]{2}{*}{ Mean } & \multirow[t]{2}{*}{ SD } & \multicolumn{2}{|c|}{ Total (\%) } \\
\hline & & & $\mathrm{N}+\mathrm{R}$ & $\mathrm{S}+\mathrm{F}$ \\
\hline $\begin{array}{l}\text { 9. Teacher correction (teacher evaluates students } \\
\text { work) : }\end{array}$ & 3.33 & 0.95 & 33.3 & 66.7 \\
\hline $\begin{array}{l}\text { 10. Peer correction (students evaluate their work) } \\
\text { : }\end{array}$ & 2.80 & 0.99 & 36.7 & 63.3 \\
\hline $\begin{array}{l}\text { 11. Self-correction (student evaluates his/her } \\
\text { work): }\end{array}$ & 3.06 & 0.96 & 36.7 & 63.3 \\
\hline $\begin{array}{l}\text { 12. Teacher-student conference: (the teacher } \\
\text { discusses the writing of students with students) }\end{array}$ & 2.83 & 1.05 & 43.3 & 56.7 \\
\hline Total & 3.00 & 0.98 & 37.5 & 62.5 \\
\hline
\end{tabular}

Level of indicator: Low =0.-1.99; moderate= 2.0-2.99; high=3.0-4.0

The result on table 5.0 above revealed a high mean (3.00), rating the overall students' preferences for the forms of correction. Item 9 indicates that majority (66.7\%, mean 3.33) of the students want the teacher to evaluate their works while item 10 indicates that most of the students $(63.3 \%$, mean $=2.80)$ like their peer to correct their errors. Again items 11 and 12 show that the students have a high preference for self-correction with $163.3 \%$, mean=3.06) and students-teacher discussion in the class about errors and correction with $(56.7 \%$, mean $=2.83)$.

In general, most of the students want all kinds of corrections as they all favourably rated all kinds of correction beyond the low level of the indicator with overall mean 3.00. However, the results revealed that those students favoured teachers' correction followed by selfcorrection and subsequently followed by peer-correction and the least favoured is teacherstudents conference.

Table 6.0: Efforts on Correction

\begin{tabular}{|c|c|c|c|c|c|}
\hline \multirow[t]{2}{*}{ Statement } & & \multirow[t]{2}{*}{ Mean } & \multirow[t]{2}{*}{ SD } & \multicolumn{2}{|c|}{ Total (\%) } \\
\hline & & & & $\mathrm{N}+\mathrm{R}$ & $\mathrm{S}+\mathrm{F}$ \\
\hline 13. Self-correction & & 3.00 & 1.11 & 36.6 & 63.4 \\
\hline 14. Teacher correction & & 2.93 & 1.14 & 46.7 & 53.3 \\
\hline $\begin{array}{l}\text { 15. Peer students } \\
\text { correction }\end{array}$ & discussion and & 2.96 & 1.06 & 43.3 & 56.7 \\
\hline Total & & 2.96 & 1.10 & 42.2 & 57.8 \\
\hline
\end{tabular}

Level of indicator: Low =0.-1.99; moderate= 2.0-2.99; high=3.0-4.0

Results in Table 6.0 revealed a moderate mean (2.96) rating the amounts of effort students are putting to eliminate errors from correction composition. Item 13 indicates that majority (63.4\%, mean=3.00) students employ self-correction, while item 14 (53.3\%, mean=2.93) shows that teacher correction is the least favoured form of correction by these students in terms of effort they made to maintain the errors and lastly, item 15 reveals that peer students discussion and correction are highly favoured by students as an effort to eradicate errors from their works or maintain the occurrence of errors in their written works. An overview of the results indicated that students highly favoured non-teacher feedback, such 
as self-correction and peer-correction while teacher correction is the least favoured form of correction these students were engaged in as measure they used presumably to control their written works.

Table 7.0: Student Strategies for Handling Feedback:

\begin{tabular}{lllll}
\hline Statement & Mean & SD & \multicolumn{2}{l}{ Total (\%) } \\
\cline { 3 - 5 } & & & $\mathrm{N}+\mathrm{R}$ & $\mathrm{S}+\mathrm{F}$ \\
\hline 16. Making a mental note. & 2.83 & 1.11 & 36.7 & 63.3 \\
17. Writing down points by type & 2.36 & 1.06 & 53.3 & 46.7 \\
18. Identifying points to be explained & 2.86 & 1.07 & 43.3 & 56.7 \\
19. Asking for teacher explanation & 3.03 & 1.06 & 33.3 & 66.7 \\
20. Referring back to previous compositions & 3.30 & 0.91 & 26.7 & 73.3 \\
21. Rewriting incorporating teacher's comments & 2.70 & 1.05 & 40.0 & 60.0 \\
22. Personal revising and expanding & 1.96 & 0.99 & 73.3 & 26.7 \\
Total & 2.72 & 1.03 & 43.8 & 56.2 \\
\hline
\end{tabular}

Level of indicator: Low =0.-1.99; moderate= 2.0-2.99; high=3.0-4.0

Results in Table 7.0 above revealed a moderate mean (2.72) rating the general overview on the students' preferences for the strategies they usually employ when they get their paper/work back to control their written compositions. Item 16 shows that majority (63.3 $\%$, mean $=2.83$ ) of students used to make a mental note for the some of the points that to be corrected, and item 17 indicates that majority $(53.3 \%$, mean=2.36) of them -in reverse case- were not focusing on writing down errors by types, let say errors in lexicon and that of syntax. Item 18 reveals that majority (56.7\%, mean 2.86$)$ used to identify some points which they need more explanation for while item 19 reports majority $(66.7 \%$, mean=3.03) of them used to consult their teachers for the points that need to be explained. Item 20 shows that majority $(73.3 \%$, mean $=3.30)$ considered previous notes on "composition" as main corrective measure for control their written errors, while item 21 reveals that most of these students $(60.0 \%$, mean $=2.70)$ engage in rewriting process only in cooperating teacher's comments and lastly item 22 indicates that most of these students $173.3 \%$, mean=1.96) were not engaging in personal revision and expanding of their written compositions. In general, the results in table above reported that among the strategies the students are employing as corrective measure for their written composition the students depend heavily on the previous notes followed by teachers consultation, other strategies favoured positively in descending order are making mental notes and rewriting in cooperating teacher's comment while personal revision is least favoured. Thus, it is reported that majority of these students rarely engaged in personal revision and identification of error to be explained. 
Section C Grammar, Spoken and written languages:

Table 8.0: Grammar, Spoken and Written Languages:

\begin{tabular}{|c|c|c|c|c|}
\hline \multirow[t]{2}{*}{ Statement } & \multirow[t]{2}{*}{ Mean } & \multirow[t]{2}{*}{ SD } & \multicolumn{2}{|l|}{ Total } \\
\hline & & & $\mathrm{N}+\mathrm{R}$ & $\mathrm{S}+\mathrm{F}$ \\
\hline 23. Grammar lesson in our class is: Interesting & 2.76 & 1.10 & 40.0 & 60.0 \\
\hline \multicolumn{5}{|l|}{$\begin{array}{l}\text { Which of the following skills do you find difficult } \\
\text { to master? }\end{array}$} \\
\hline \multirow[t]{2}{*}{ 24. Speaking } & 2.70 & 1.14 & 43.3 & 56.7 \\
\hline & 2.60 & 1.00 & 43.3 & 56.7 \\
\hline 25. Writing & & & & \\
\hline $\begin{array}{l}\text { 26. I do not know the differences between } \\
\text { written and spoken language }\end{array}$ & 2.86 & 1.13 & 36.7 & 63.3 \\
\hline Total & 2.73 & 1.09 & 40.82 & 59.1 \\
\hline
\end{tabular}

Level of indicator: Low =0.-1.99; moderate= 2.0-2.99; high=3.0-4.0

The result in Table 8.0 above revealed moderate mean (2.73) rating the overall perception of the students about grammar lessons, and differences between two skills of language: writing and speaking. Item 23 shows that majority of these students $(60.0 \%$, mean=2.7) were interested in a grammar lesson. Items $24(56.7 \%$, mean=2.76) and $25(56.7 \%$, mean $=2.60$ ) reveal that students found both skills writing and speaking to be difficult for them to master while item 26 indicates that majority of them $(63.3 \%$, mean $=2.60)$ did not know the differences between writing and speaking skills. Overall view, the results in the above table reported that most of these students like a grammar lesson. On the other hand, students face difficulties in learning and mastering writing, and speaking skills and the majority of them cannot differentiate between different processes involved in the two.

Table 9.0: Composition Exercises:

\begin{tabular}{lllll}
\hline Statement & Mean & SD & \multicolumn{2}{l}{ Total } \\
\cline { 4 - 6 } & & & $\mathrm{N}+\mathrm{R}$ & $\mathrm{S}+\mathrm{F}$ \\
\hline 27. My Arabic teacher gives an assignment on & 2.5 & 1.07 & 46.7 & 53.3 \\
$\begin{array}{l}\text { composition exercises } \\
\text { 28. I practice writing composition at home }\end{array}$ & 2.9 & 1.06 & 43.3 & 56.7 \\
total & 2.7 & 1.06 & 45.0 & 55.0 \\
\hline
\end{tabular}

Level of indicator: Low =0.-1.99; moderate= 2.0-2.99; high=3.0-4.0

Results in a Table 9.0 above showed a moderate mean (2.7) rating the overall perception of students for composition exercises. Item 27 in which students were required to rate the how frequent their teachers give an assignment on written composition. It revealed that majority of the students reported that their teachers are not giving an assignment on the composition exercises. And item 28 indicated that majority of the students practice writing at home.

The findings correspond with the results in Yahya et al., (2016) study who found that writing of Malaysian undergraduate Arabic learners' errors in the tenses use are most frequent 
errors made by the participants in which 229 errors were committed by 28 students out of 30. Other errors comprise of the use of an article, errors in a preposition, errors in using singular and plural, and errors in spelling. It was inconsistent with the work of Hassan (2017) who studies errors of written Arabic essays by the Terengganu diploma students of the Arabic language. His study reveals that the student committed ten common errors among which tense miss used has the highest frequency.

\section{Conclusion}

Based on the findings of the present study, the researcher concluded that UNISZA AFL students produced sentence fragments frequently in their compositions as such sentence fragments were found 91 instances from the letters written by 30 students who participated in the written test session. Fragments produced by the students who participated in this study were attributed to intra-lingual source except in a few instances where first language influence was viewed as part of the sources of the errors. While other factors explored that might contribute to sentence error especially fragments can be seen from three factors; teachers' factors, students factors, and situational factors. Perspectives from teachers' factors were sought concerning ways they are dealing with students' composition. The study revealed that teachers rarely give a correction or use codes to indicate errors even when they do so they doing it holistically without paying attention to individual errors or the gravity of one error over the others. Implacably, this may cause students to continuously be making unnecessary errors in their writing.

\section{Recommendations}

Based on the purposes of the study and in the light of findings revealed in the present study, the researchers drew the following implications and suggestions for further studies. The researchers recommended that teaching of language especially at begging and intermediate levels teachers are encouraged to understand the nature of writing as a process as well as the product. They should concentrate on teaching students writing skills to enable the students to know the causes of grammatical and syntactical weaknesses in their writings. This can be achieved by examining the areas that need reinforcement in teaching second language learners writing. Moreover, it will be helpful for teachers to employ a good method to enhance teaching grammar to the university students. The study also recommended that students should put more efforts in learning and apply the basic principles of grammar and writing skills. Finally, the researchers recommended that more studies should be conducted in this area. It suggested that more investigation should be carried out on the causes of fragments in relation from teachers' perspectives as well as the method of teaching the Arabic language.

\section{References}

Ahmad, Z. A. (2003). Arabic Writing Skills among Malay Students. (Unpublished doctoral dissertation). Malaysia: Malaya University.

Alhirtani, N. A. (2018). The Influence of Arabic Language Learning on Understanding of Islamic Legal Sciences-A Study in the Sultan Idris Education University. International Education Studies, 11(2), 55. 
Al-Sobhi, B. M. S., Rashid, S. M., Abdullah, A. N., \& Darmi, R. (2017). Arab ESL Secondary School Students' Spelling Errors. International Journal of Education and Literacy Studies, 5(3), 16-23.

Bawa, P., \& Watson, S. L. (2017). A Phenomenological Study of Graduate Chinese Students' English Writing Challenges. The Qualitative Report, 22(3), 779.

Brindley, G. P. (1986). The assessment of second language proficiency: Issues and approaches. National Curriculum Resource Centre [for the] Adult Migrant Education Program Australia.

Corder, S. P., (1973) Introducing Applied Linguistics. London, UK: Pelican Books.

Coulmas, F. (2017). An Introduction to Multilingualism: Language in a Changing World. Oxford University Press.

Ferris, D. (2011). Treatment of error in second language student writing. Michigan, USA: University of Michigan Press.

Haron, S. C., Ahmed, I. H., Mamat, A., Ahmad, W. R. W., \& Rawash, F. M. M. (2016). Challenges in Learning to Speak Arabic. Journal of Education and Practice, 7(24), 8085.

Harpin, W. S. (2017). The second'R': writing development in the junior school. London, UK: Taylor \& Francis.

Hassan, M.M.S. (2017).Error Analysis of Written Arabic Essays: The Case of Diploma Students in Terengganu, Malaysia. English for Specific Purpose World, 40,14-29.

Jaafar, W. N. W. (2011). Efficiency of Writing Skills among Student Islamic Secondary Class in Kota Setar, Kedah: National University of Malaysia

Lavelle, E., Smith, J., \& O'Ryan, L. (2002). The writing approaches of secondary students. British Journal of Educational Psychology, 72(3), 399-418.

Mei, S. Y., Ju, S. Y., \& Mohd, A. B. (2017). Cooperative Learning Strategy in teaching Arabic for Non-Native Speakers. European Journal of Social Sciences Education and Research, 11(2), 261-266.

Mohad, A. H., Mokhtar, R. A. M., \& Omar, N. (2018). The Religious Practices of Deaf Muslims in Malaysia: A Case Study at the Special Education School. INSANCITA, 3(1).

Pienemann, M., \& Kessler, J. U. (2012). Processability theory. The Routledge handbook of second language acquisition, 228-247.

Rahman, A. A. (2017). Ways to activate the teaching of Arabic linguistics and its effects on non-Arabic speakers in Malaysian universities: An analytical, descriptive study. International Journal, 2(6), 1-33.

Scott, B. J., \& Vitale, M. R. (2003). Teaching the writing process to students with LD. Intervention in school and clinic, 38(4), 220-224.

Shintani, N., \& Ellis, R. (2015). Does language analytical ability mediate the effect of written feedback on grammatical accuracy in second language writing?. System, 49, 110119.

Ting, S. H. (2017). Language choices of CEOs of Chinese family business in Sarawak, Malaysia. Journal of Multilingual and Multicultural Development, 38(4), 360-371.

Veloo, A., Krishnasamy, H. N., \& Harun, H. M. (2015). What Are the Learning Approaches Applied by Undergraduate Students in English Process Writing Based on Gender?. International Education Studies, 8(6), 46. 
INTERNATIONAL JOURNAL OF ACADEMIC RESEARCH IN BUSINESS AND SOCIAL SCIENCES

Vol. 8, No. 6, June 2018, E-ISSN: 2222-6990 @ 2018 HRMARS

Yahya, A., Ishak, H. B., Zainal, Z., Faghat, L. J., \& Yahaya, N. (2016). Error analysis of Arabic learners' writings, a case study. International Islamic University Malaysia. IPEDR, 33, 459-654.

Zailaini, M. A., Ismail, W., \& Azhar, A. N. M. (2018). Strategies for Promoting Students to Communicate in Communicative Language Teaching of Arabic Classroom. Advanced Science Letters, 24(1), 172-174. 